\title{
RESONANT TUNNELING IN A DOUBLE-BARRIER JOSEPHSON JUNCTION
}

\author{
P. Shygorin ${ }^{1}(\mathbb{D})$ B. Venhryn ${ }^{2}$ (D) \\ ${ }^{1}$ Lesya Ukrainka Volyn National University, 13, Volya Ave., Lutsk, UA-43025, Ukraine, \\ ${ }^{2}$ Lviv Polytechnic National University, 12, Bandera St., Lviv, UA-79013, Ukraine \\ (Received 31 August 2020; in final form 18 November 2020; accepted 19 November 2020; \\ published online 14 December 2020)
}

\begin{abstract}
The present paper presents an investigation of the current states in a double barrier tunnel Josephson junction. The Josephson supercurrent in tunnel multilayered structures has significant features related to the phenomenon of quantum resonant tunneling. The value of the supercurrent is very sensitive to the distance between the barriers (thickness of interior superconductor layer). This gives a possibility to fabricate the tunnel Josephson junctions with hight values of critical supercurrent. In this paper the relationship for the thickness of an interior superconductor layer has been found for which the double-barrier becomes fully transparent. We also investigated the current-phase relation for the double barrier tunnel Josephson junction, derived the equation for the critical value of a supercurrent and calculated the skewness in the current-phase relation for different values of the transparency of the junction.
\end{abstract}

Key words: Josephson junction, resonant tunneling, current-phase relation, skewness.

DOI: https://doi.org/10.30970/jps.24.4706

\section{INTRODUCTION}

Josephson junctions (JJ) are very attractive objects for investigation in modern physics of condensed matter. They are interesting from a fundamental perspective as well as for applications in technologies. There are many branches of theoretical investigations of JJ. They include the phenomenon of the spontaneous symmetry breaking, the dissipative behavior of supercurrent, the expulsion of the magnetic flux, and so forth [1]. In the recent years, we have seen a lot of articles related to topological superconductivity. The topological Josephson junction reveals important information about this phenomenon [2]. In technologies, there are many devices and highsensitivity detectors based on the JJ. They include superconducting quantum interference devices (SQUIDs), rapid single flux quantum (RSFQ) digital devices, superconducting qubits. JJ also have applications in voltage metrology.

Typical JJ have the following configurations: SIS, SNS, SFS (here $\mathrm{S}$ is the superconductor, $\mathrm{I}$ is the insulator, $\mathrm{N}$ is a normal metal, $\mathrm{F}$ is a ferromagnet). In recent years, it has become possible to create multilayered (also known as "sandwich") Josephson structures of the SINIS and SISIS-type [3]. The Josephson effect in tunnel multilayered structures has significant features that are related to the phenomenon of quantum resonant tunneling. The value of a Josephson supercurrent is dependent on the transparency of the junction. For the multilayered junction there is a possibility of controlling the transparency by tuning the spacing between layers. Hence, we obtain a possibility to fabricate the tunnel JJ with hight values of critical supercurrent.

In the present paper, we carry out a microscopic investigation of the resonant tunneling effects in a double-barrier Josephson SISIS-junction. We investigate the relationship between the critical current, the coherent phase difference and the transparency of the junction. Also, we calculate the skewness in the currentphase relation for the SISIS junction.

\section{MODEL}

Let us consider a double barrier tunnel junction with geometry SISIS ( $\mathrm{S}$ is a superconductor, $\mathrm{I}$ is an insulator). In this paper, we will investigate the so-called point junction. From the microscopic point of view, for this type of junction electrons incident on the barrier at the right angle (i. e. the electron's momentum $p \cong p_{z}$ ). The geometry of the tunnel junction is shown on Fig 1.
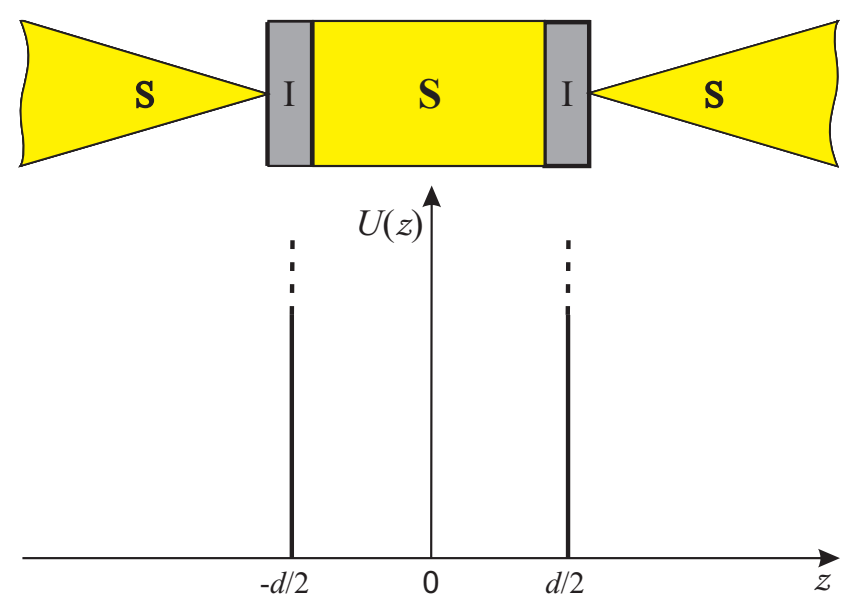

Fig. 1. Model of the symmetric SISIS tunnel junction and corresponding potential 
The insulators are modeled by a delta-Dirac potential barriers

$$
U(z)=\alpha\left[\delta\left(z-\frac{d}{2}\right)+\delta\left(z+\frac{d}{2}\right)\right] .
$$

Here $\delta(z)$ is the Dirac delta function.

Typical insulators used for the tunnel junctions (e.g., $\mathrm{Al}_{2} \mathrm{O}_{3}$ ) have the thickness of about $10-20 \mathrm{~nm}$. The barrier height is about $1-5 \mathrm{eV}$. Hence, the constant $\alpha$ for the delta-Dirac potential (1) is about $(1-10) \times 10^{-8}$ $\mathrm{eV} \cdot \mathrm{m}$.

The solution of the Schrödinger equation with potential (1) gives the next relation for the transparency of the double-barrier junction:

$$
D=\frac{\kappa^{4}}{\kappa^{4}+\left(\kappa \cos \left(p_{z} d\right)+\frac{1}{2} \sin \left(p_{z} d\right)\right)^{2}},
$$

where

$$
\kappa=\frac{p_{z}}{2 m \alpha}=\frac{\sqrt{E}}{\sqrt{2 m} \alpha} .
$$

Here $E$ is the energy of incident on the barrier electron.

According to the superconductivity theory, the characteristic momenta that contribute to the values of physical quantities are close to the Fermi momentum $p_{\mathrm{F}}$. So, we may assume that parameter $\kappa$ is approximately equal

$$
\kappa=\frac{p_{\mathrm{F}}}{2 m \alpha}=\frac{\sqrt{E_{\mathrm{F}}}}{\sqrt{2 m} \alpha} .
$$

The Fermi energy for metals is about $2-10 \mathrm{eV}$, then parameter $\kappa$ takes on the values within the interval (530) $\times 10^{-3}$.

We note that in the case

$$
\kappa \cos \left(p_{z} d\right)+\frac{1}{2} \sin \left(p_{z} d\right)=0
$$

the double-barrier becomes fully transparent, even though the partial transparency of each barrier can be small! It is the effect of the resonant tunneling of electrons. This phenomenon is similar to the enlightenment of optics.

The current states in a SISIS junction can be investigated using equations of the microscopic theory of superconductivity. In the paper [4], using the approach of the quasiclassical equation for Green's function, an expression for the supercurrent through a double-barrier Josephson junction was obtained

$$
\begin{aligned}
& j=j_{0} \frac{D \sin \varphi}{\sqrt{1-D \sin ^{2} \frac{\varphi}{2}}} \tanh \frac{\Delta \sqrt{1-D \sin ^{2} \frac{\varphi}{2}}}{2 T} \\
& j_{0}=\frac{\pi}{4} e v_{\mathrm{F}} N_{\mathrm{F}} \Delta .
\end{aligned}
$$

Here $N_{\mathrm{F}}=\frac{3}{4} \frac{n}{E_{\mathrm{F}}}$ is the density of states at the Fermi surface, $D$ is the transmission coefficient for the double delta-function barrier (2), $\Delta$ is the gap in the spectrum of excitations in a superconductor, $T$ is the temperature, $\varphi$ is the phase difference between the superconductors. The analysis of the properties of the current (4) will be provided in the next section.

\section{RESULTS}

Let us consider some features of the Josephson current in a double-barrier junction, which is described by equation (4) with transparency (2). We calculate the current at the temperature $T=2.5 \mathrm{~K}$ for a tunnel junction on the basis of niobium, for which the energy gap $\Delta \simeq 3 \mathrm{meV}$, critical temperature $T_{\mathrm{c}} \simeq 9.5 \mathrm{~K}$, density of states $N_{\mathrm{F}} \simeq 5.56 \times 10^{28} \mathrm{~m}^{-3}$, and Fermi velocity $v_{\mathrm{F}} \simeq 1.37 \times 10^{6} \mathrm{~ms}^{-1}$. For this case $\Delta / T \simeq 14.2$ and

$$
j_{0}=\frac{\pi}{4} e v_{\mathrm{F}} N_{\mathrm{F}} \Delta \simeq 4.59 \mu \mathrm{A} / \mathrm{m}^{2}
$$

The supercurrent through the SISIS junction is different from the current in the case a SIS-junction. It has a nonmonotonous dependence on the distance between barriers, with the presence of resonance peaks (see Figs. 2, 3). This is lined to the resonant tunneling of Cooper pairs through the double-barrier structure.

Using equation (3), we can calculate the values of a barrier thickness that correspond to resonance peaks of the supercurrent. When the thickness of the interior superconductor layer satisfies the condition

$$
\tan \left(p_{\mathrm{F}} d_{\max }\right)=-2 \kappa,
$$

then the current reaches the maximum.

For the case $\kappa=0.01$, equation (5) gives the following values

$$
p_{\mathrm{F}} d_{\max }=3.12,6.26,9.40, \ldots .
$$

Another feature of the supercurrent in a double Josephson junction (4) is that it exhibits a non-sinusoidal current-phase relation. The current-phase relation for a SISIS-junction at different values of the transparency $D$ is shown in Fig. 4.

The value of the critical current $j_{\max }$ can be found as an extremum of the supercurrent (4) with respect to the phase difference $\varphi$. The critical value of the superconducting phase difference satisfies the equation

$$
\varphi_{\max }=\arccos \left[1-\frac{2}{D}\left(1-x^{2}\right)\right],
$$

where $x$ is the root of the transcendental equation

$$
\sinh \left(\frac{\Delta}{T} x\right)=\frac{\Delta}{T} \frac{x^{2}\left(1-x^{2}\right)\left(1-D-x^{2}\right)}{1-D-x^{4}} .
$$

Let us compute the critical current at $T=2.5 \mathrm{~K}$ for a junction based on niobium with the energy gap $\Delta \simeq 3$ $\mathrm{meV}$, critical temperature $T_{\mathrm{c}} \simeq 9.5 \mathrm{~K}$, density of states $N_{\mathrm{F}} \simeq 5.56 \times 10^{28} \mathrm{~m}^{-3}$, and the Fermi velocity $v_{\mathrm{F}} \simeq$ $1.37 \times 10^{6} \mathrm{~ms}^{-1}$. For this case $\Delta / T \simeq 14.2$ and

$$
j_{0}=\frac{\pi}{4} e v_{\mathrm{F}} N_{\mathrm{F}} \Delta \simeq 4.59 \mu \mathrm{A} / \mathrm{m}^{2}
$$




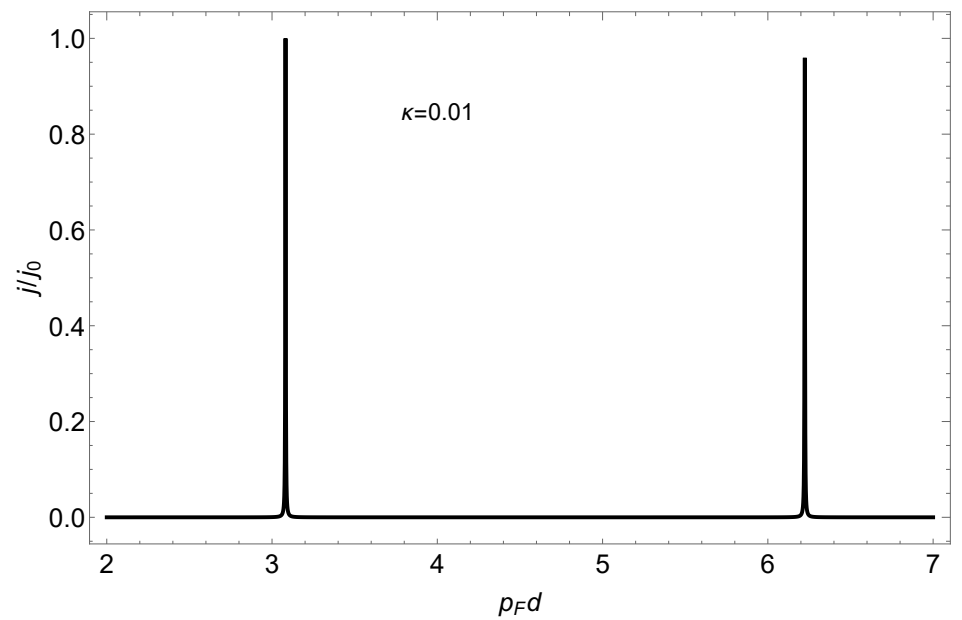

Fig. 2. Dependence of the current density on the distance between the barriers (thickness of interior superconductor layer). The current density is normalized to the value $j_{0}=\frac{\pi}{4} e v_{\mathrm{F}} N_{F} \Delta$

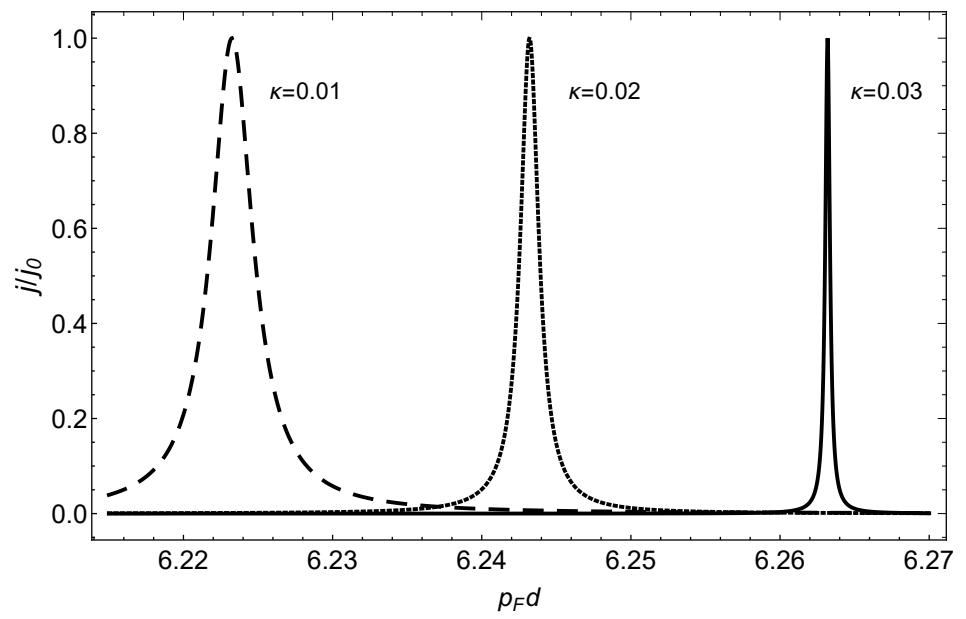

Fig. 3. Dependence of the current density on the distance between the barriers at the different values $\kappa$. The current density is normalized to the value $j_{0}=\frac{\pi}{4} e v_{\mathrm{F}} N_{F} \Delta$

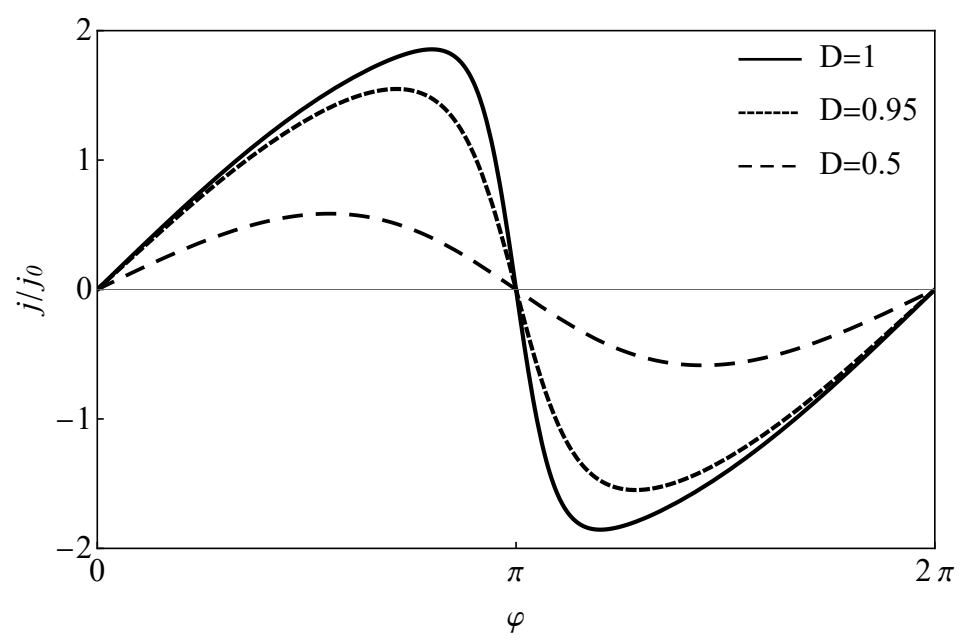

Fig. 4. Current-phase relation curves for a SISIS-junction at different values of the transparency $D$. The current density is normalized to the value $j_{0}=\frac{\pi}{4} e v_{\mathrm{F}} N_{F} \Delta$ 
For the case of the perfect transparency, $D=1$, the root $x \simeq 0.23$ and $\varphi_{\max }=2.67, j_{\max } \simeq 1.94 j_{0} \simeq$ $8.9 \mu \mathrm{A} / \mathrm{m}^{2}$.

For $D=0.5$, we obtained $x \simeq 0.84, \varphi_{\max }=1.75$, $j_{\max } \simeq 0.59 j_{0} \simeq 2.7 \mu \mathrm{A} / \mathrm{m}^{2}$.

In Ref. [5], to identify the behavior of Josephson junctions, the skewness $S$ in the current-phase relation has been defined as follows

$$
S=\frac{2}{\pi} \varphi_{\max }-1
$$

In the current-phase relation skewness defines the degree of the deviation of the Josephson supercurrent from a sinusoidal form.

In the current-phase relation skewness for the doublebarrier tunnel junction is:

$$
S=\frac{2}{\pi} \arccos \left[1-\frac{2}{D}\left(1-x^{2}\right)\right]-1,
$$

where $x$ is a root of the equation (6).

The skewness is dependent on the transparency of the junction as well as on the ratio $\Delta / T$. For the junction considered in the present paper, we get the following values

$$
S_{D=0.5}=0.62, \quad S_{D=1}=-0.79 \text {. }
$$

Skewness can be measured experimentally by a phasesensitive SQUID interferometry technique [6].

\section{CONCLUSIONS}

In this work, we considered current states in a double barrier tunnel Josephson junction with geometry SISIS. The Josephson supercurrent in this junction has significant features that are related to the phenomenon of quantum resonant tunneling. Particulary, the value of the supercurrent is very sensitive to the distance between the barriers (thickness of interior superconductor layer). At the supercurrent pattern, there is presence of resonance peaks, which is linked to the resonant tunneling of Cooper pairs through the double-barrier structure. We have found the relationship for the thickness of the interior superconductor layer, for which the doublebarrier becomes fully transparent, even though the partial transparency of each barrier can be small.

Also we investigated the current-phase relation for the double barrier tunnel Josephson junction. We have established an equation for the critical value of the supercurrent and calculated the skewness in the currentphase relation for different values of the transparency of the junction.
[1] A. V. Svidzynskyi, Microscopic Theory of Superconductivity (Vezha, Lutsk, 2011) [in Ukrainian].

[2] B. de Ronde, C. Li, Y. Huang, A. Brinkman, Nanomaterials 10, 794 (2020); https://doi.org/10.3 390/nano10040794.

[3] P. Seidel, Applied Superconductivity: Handbook on Devices and Applications (Wiley-VCH, Berlin, 2015).
[4] P. Shygorin, A. Svidzynskyi, I. Materian, Ukr. J. Phys. 62, 518 (2017); https://doi.org/10.15407/ujp e62.06.0518.

[5] R. de Luca, Phys. Lett. A 375, 2441 (2011); https:// doi.org/10.1016/j.physleta.2011.05.004.

[6] C. D. English et al., Phys. Rev. B 94, 115435 (2016); https://doi.org/10.1103/PhysRevB.94.115435.

\title{
РЕЗОНАНСНЕ ТУНЕЛЮВАННЯ У ДВОБАР'ЄРНОМУ ДЖОЗЕФСОНІВСЬКОМУ КОНТАКТІ
}

\author{
П. Шигорін ${ }^{1}$, Б. Венгрин ${ }^{2}$ \\ ${ }^{1}$ Волинсъкий націоналъний університет імені Лесі Украйнки \\ пр. Волі, 13, Лучък, 43000, Украӥна, \\ ${ }^{2}$ Націоналъний університет “Лъвівсъка політехніка", вул. Ст. Бандери, 12, м. Лъвів, 79013, Украӥна \\ У роботі подано результати вивчення струмових станів у двобар'єрному джозефсонівському кон- \\ такті. Досліджуваний тунельний контакт має структуру SISIS (S позначає надпровідник, I - iзоля- \\ тор). Надпровідний струм у багатошарових структурах має якісні відмінності від струму в "класи- \\ чному" тунельному контакті (наприклад, структури SIS). Ці відмінності передусім пов'язані з кван- \\ товим резонансним тунелюванням. Розглянутий у роботі SISIS- контакт моделюється подвійним \\ дельта-функційним потенціальним бар'єром. Коефіцієнт проходження електронів через подвійний \\ бар'єр залежить від відстані між бар'єрами. За певних значень цієї відстані коефіцієнт проходження \\ дорівнює одиниці, тобто бар'єр стає абсолютно прозорим для електронів. \\ У роботі показано, що значення надпровідного струму через двобар'єрний контакт дуже чутливе \\ до відстані між бар'єрами. Отже, регулюючи цю відстань, можна створювати надпровідні контакти \\ з високим значенням критичного струму. Ми обчислили, за яких значень товщини внутрішнього
}


надпровідного прошарку виникає резонансне тунелювання, й одержали рівняння для критичного значення струму та розрахували його значення для різних прозоростей на прикладі тунельного контакту $\mathrm{NbAl}_{2} \mathrm{O}_{3} \mathrm{NbAl}_{2} \mathrm{O}_{3} \mathrm{Nb}$. Також у роботі досліджено залежність надпровідного струму від когерентної різниці фаз надпровідників, що утворюють контакт. Показано, що за зростання коефіцієнта проходження електронів через бар'єр залежність джозефсонівського струму неперервно змінює форму від синусоїдної до пилкоподібної.

Для кількісного опису форми залежності тунельного струму від когерентної різниці фаз на берегах контакту запроваджено й розраховано скошеність у залежності струму від різниці фаз. Скошеність у залежності струму від різниці фаз є важливим параметром тунельного контакту, оскільки вона може бути безпосередньо виміряна експериментально за допомогою фазочутливої SQUID-інтерференційної техніки. Одержані в роботі теоретичні підходи можна перенести на тунельні контакти іншої геометрії (наприклад, $\mathrm{S}_{1} \mathrm{IS}_{2} \mathrm{IS}_{3}$ ).

Ключові слова: джозефсонівський контакт, резонансне тунелювання, надпровідний струм, когерентна різниця фаз, скошеність. 